\title{
Marital Rape: An Evaluation of the Patriarchal Injustice in the Criminal Law (Amendment) Act, 2013
}

\author{
Shivika Choudhary*
}

\section{Abstract}

The traditional belief that marriage provides a husband with sole rights over his wife, thereby exempting him from any prosecution for raping his wife, has been the justification for denying a woman the right to consent to sexual intercourse in marriage. Unfortunately, this belief has been a source of subjugation and exploitation of women at the behest of their husbands. Despite recommendations to revoke it, the Criminal Law (Amendment) Act, 2013 has retained the marital exception. The purpose of this article is to examine this dichotomy in the Criminal Law (Amendment) Act, 2013 that punishes rape as such, but does not penalise a husband raping his wife of fifteen years or above.

Employing doctrinal method of research, this article analyses the various discrepancies and ambiguities in the Act of 2013 that perpetuate this culture of oppression and violence. Consent is the antithesis to rape. Thus, having examined the need for a married woman's right to consent, this note examines the ensuing lacunae that grant legal sanction to child marriages, create an unexplained discrepancy in the punishment for rape, and create variations in the age of consent and the age for availing exception. The recognition of marital rape when spouses live separately and not otherwise appears to be a mysterious distinction. Further, treatment of marital rape

* Doctoral Research Scholar (Legal Studies), South Asian University, New Delhi; shivika.c@nls.ac.in. The author expresses her sincere gratitude to her professor and mentor Dr. Anuradha Saibaba for introducing her to this legal issue and for providing valuable inputs. 
as a civil wrong rather than as a crime is a reflection of the patriarchal notion that still treats a woman as her husband's property. It is argued that marriage establishes a relation of trust, the infringement of which demands greater accountability and punishment. This article analyzes these provisions, which evidence the patriarchal frame of mind that silences women's voices in the conjugal domain.

Keywords: Age of Consent, Criminal Law (Amendment) Act, 2013, Marital Rape, Right to Consent, Verma Committee Report 2013.

\section{Introduction}

"The husband cannot be guilty of a rape committed by himself upon his lawful wife, for by their mutual matrimonial consent and contract the wife hath given herself up in this kind unto her husband which she cannot retract."

-Sir Matthew Hale ${ }^{1}$

The traditional belief that marriage provides a husband with the 'license to rape', thereby exempting him from any prosecution for raping his wife is evidenced by the above quote. Outlawing this traditional notion, Justice Brennan of Australian High Court, observed in 1991 that "[ $\mathrm{t}]$ he common law fiction has always been offensive to human dignity and incompatible with the legal status of a spouse". 2 Surprisingly, India has refrained from outlawing marital rape even though it is the most common and repugnant form of masochism in Indian society, which remains hidden behind the veil of marriage. ${ }^{3}$ Research indicates that marital rape has severe and long lasting consequences for women, both physical

1 Sir Matthew Hale, History of the Pleas of the Crown 629 (1736); See, S. FREDMAN, WOMEN AND THE LAW 55-57 (1997).

2 R v. L [1991] H.C.A. 48; (1991) 174 C.L.R. 379, 40, 2.

3 See generally, K.N.CHANDRASHEKHARAN PILlAi, WOMEN AND CRIMINAL PROCEDURE, ENGENDERING LAW, ESSAYS IN HONOR OF LOTIKA SARKAR (Amita Dhanda \& Archana Parashar Eds., 1999); DWARKA NATH MITTER, The Position of Women in Hindu LAW (1913); A.S. Altekar, The POSITION OF WOMEN IN Hindu CiVILIZATION (2nd ed. 1959). 
and psychological. ${ }^{4}$ Physical effects include injuries to private organs, miscarriages, stillbirths, bladder infections, infertility and the potential contraction of sexually transmitted diseases like HIV/AIDS. Women raped by their partners also suffer severe psychological consequences such as flashbacks, sexual dysfunction, and emotional pain, for years after violence. ${ }^{5}$

As per the report by the National Crime Records Bureau, 'Crime in India 2012,'6 offenders were known to the rape victims in as many as $24,470(98.2 \%)$ cases and about $1.6 \%$ of these cases involved parents and close family members. This minor percentage is also a reflection of the fact that marital rape is not regarded as a crime per $s e$, and hence is sparingly reported. Despite the recommendations of Justice Verma Committee (JVC Report) ${ }^{7}$ to criminalize marital rape, the exception to section 375 of Indian Penal Code, 1860 (IPC), which grants an exemption to sexual intercourse by husband with his wife of above fifteen years of age, is retained. This legislative note analyses the patriarchal and chauvinistic notion that is evidenced in the Criminal Law (Amendment) Act 2013. ${ }^{8}$

\section{Women's Right to Consent: The Dilemma}

"The being of a woman is suspended during the marriage, or at least is incorporated and consolidated into that of her husband, under whose wing, protection and cover she performs everything."

\footnotetext{
${ }^{4}$ R. Thornhill \& C. T. PAlmer, A Natural History of RAPE-Biological BASES OR SEXUAL COERCION (1 ed., 2000); R. THORNHILl \& N. THORNHILL, THE Evoluion of Pschological Pain, IN SOCIOLOGY AND SOCIAL SCIENCE (R. Bell N. Bell eds., 1989).

${ }^{5} \mathrm{Id}$.

${ }^{6}$ Ministry of Home AfFairs, National Crime Records Bureau, Crime in India 2012, Chapter 5, available at http:/ / ncrb.gov.in/ (last visited Mar. 10, 2014).

7 JUStice Verma COMmittee On AMENDMENTS to CRiminal LAW, Report of the Committee on Amendments to Criminal Law (January 23, 2013).

8 The Criminal Law (Amendment) Act, 2013.
} 
- Justice Blackstone ${ }^{9}$

The hesitation in recognizing marital rape is premised on the chauvinistic understanding that a woman is the property of her husband ${ }^{10}$ and rape laws have, in essence, existed to safeguard the masculine pride in the exclusive possession of a sexual object. ${ }^{11}$ This section reflects on the arguments that favour or abhor this sinister belief that a married woman is bereft of any right to consent.

\section{Is Woman's Consent Material?}

The JVC Report noted that exemption of marital rape reduces women to 'no more than the property of their husbands'. ${ }^{12}$ This is the patriarchal notion that has fuelled this injustice. A woman, however, cannot be relegated to the status of a chattel ${ }^{13}$, and has an identity different from that of her husband. Further, a married woman has the same right to exercise control over her body as an unmarried woman. ${ }^{14}$ The other contention that the State does not want to interfere in the domain of the marital home does not hold good because the right to privacy protects only consensual acts and not violent sexual assaults. Similarly, it is not difficult to understand that the marriage becomes irredeemable when intercourse is accomplished by violent assault or coercion.

Another rationale that is advanced is that marital rape would be difficult to prove in the court and vindictive wives may falsely implicate their husbands. It is submitted that despite the existence of section 114A of the Indian Evidence Act, 1872 (IEA), proving

\footnotetext{
${ }_{9}^{9}$ BlACKSTONE, COMMENTARIES ON ENGLISH LAW 442 (PUB, 1844); See, supra note 1.

${ }_{10}$ Charlotte L. Mitra, For She Has No Right To Give Consent, 1979 Cr. L. J 558.

11 JUlia R. \& HERMAN SCHEWENDINGER, RAPE AND INEQUALITY 95 (PUB. 1993).

12 Supra note 7 at 112.

13 L.H.V Prasad v. Station House Officer, Alwal Police Station, 1999 Cr.L.J. 3928 (A.P.).

14 People v. Liberta, 64 N.Y. 2nd 152, 485 N.Y.S. $2^{\text {nd }} 207$ (1984). 
lack of consent is the most difficult part in any rape prosecution. If this be the logic, then virtually all crimes other than homicide should go unpunished for failure to provide overwhelmingly believable evidence. ${ }^{15}$ The final argument put forward by male chauvinists is that marital rape is not as serious an offence as other rape and is thus adequately dealt with in legislations such as the Domestic Violence Act, 2005. It is submitted that a crime should be punished under penal laws and not compensated for under civil laws.

The observations of the apex court in Vishakha $v$. State of Rajasthan ${ }^{16}$ and Apparel Export Promotion Council v. A.K. Chopra, ${ }^{17}$ state that the right to be protected from sexual harassment and sexual assault is guaranteed by the Constitution, and is one of the pillars on which the very construct of gender justice stands. Thus, a woman's right to exercise autonomy over her body is in consonance with the right to live with dignity and equality, a value cherished in our Constitution and in international instruments. ${ }^{18}$

The statutory definition of rape in India emphasizes the absence of consent, an important aspect of the actus reus of the offence, as per the $84^{\text {th }}$ Law Commission Report ${ }^{19}$. However, in the case of a married woman, consent is nothing more than an over rated

15 V. Barshis, The Question of Marital Rape, 6 WOMEN'S STUDIES INTERNATIONAL FORUM 383, 383-393 (1983).

16 A.I.R. 1997 S.C. 3011.

17 A.I.R. 1999 S.C. 625.

18 See generally THE CONSTITUTION OF INDIA, Art. 21; International Covenant on Civil and Political Rights, art. 10 Dec. 16, 1966, 999 UNTS 171; International Covenant on Economic, Social and Cultural Rights, preamble, arts. 12, 13 Dec. 16, 1966, 993 UNTS 3; THE CONSTITUTION OF INDIA, Arts. 14, 15, 16; International Covenant on Economic, Social and Cultural Rights, preamble, arts. 3, 7, 13 Dec. 16, 1966, 993 UNTS 3; International Covenant on Civil and Political Rights, preamble, arts. 3, 14, 23, 26 Dec. 16, 1966, 999 UNTS 171; Universal Declaration of Human Rights, art. 16 .A. res. 217A (III), U.N. Doc A/810 at 711948.

${ }^{19}$ LAW COMMISSION OF INDIA, 84 th Report on Rape and Allied Offences: Some Questions of Substantive Law, Procedure and Evidence (1980), available at http:/ /lawcommissionofindia.nic.in/51-100/Report84.pdf. (last visited 10 Mar. 2014). 
illusion. Section 375 of Indian Penal Code, 1860 contains seven descriptions regarding consent, wherein consent of a woman below eighteen years is irrelevant to constitute the offence of rape. Exception 2 to section 375, on the contrary, absolves a man from the offence of rape for sexual intercourse with his wife of fifteen years of age. Firstly, this grants a license to the husband to have sexual intercourse with his wife of fifteen years without her consent. Secondly, it forgoes the right of the wife to grant/abstain from granting consent after eighteen years of age. Thirdly, when compared with section 376 (2) (i) of IPC, which punishes rape of a woman under sixteen years of age with rigorous imprisonment of minimum ten years to life imprisonment, the exemption under section 375 seems to be hypocritical as it condones the act itself.

It is submitted that overt violence of any category is not a necessary element of rape as defined in section 375 . Rather, the cardinal fact is the absence of consent on the part of the woman. In order to absolve one of criminal liability in a case of rape, the consent should be real. ${ }^{20}$ Explanation 2 to section 375 provides that 'consent means an unequivocal voluntary agreement' which can be vitiated by circumstances that take away the freedom of choice. A combined reading of section 90 of IPC (deals with consent for the purposes of the Code) and seven clauses in section 375 provide grounds of vitiation, which includes against will; without consent; consent obtained in fear of death or hurt; misrepresentation as being her husband; unsoundness of mind; intoxication or administration of stupefying substance(s); under eighteen years of age; and inability to communicate consent. The Law Commission Report (LCR), 1980 noted that 'consent should be active consent, as distinguished from that consent which is said to be implied by silence. ${ }^{21}$ Surprisingly, the exemption given to sexual intercourse of man with his wife has necessarily eliminated the requirement of any voluntary consent. Thus, a woman may be under duress or coercion or intoxication, and yet, her husband can rape her without her free and voluntary consent.

$20 \mathrm{Id}$. at 7. See also LAW COMMISSION OF INDIA, 42nd Report on Indian Penal Code (1971), available at http://lawcommissionofindia.nic.in/150/Report42.pdf (last visited 10 Mar. 2014).

21 Supra note 17 at 8 .

102 
The author submits that section 114A of the Indian Evidence Act deals with presumption of absence of consent in certain rape cases provided under section 376 (2) of IPC, where if the sexual intercourse is proved and the woman denies consent, then the court 'shall' presume absence of consent. Thus, a mandatory presumption is placed on the court if for instance, among other cases, the woman is under sixteen years of age, or the offender is a person in a position of trust or authority over the woman. This presumption does not apply when a woman of fifteen years or over is raped by her husband who holds a position of trust, as it stands exempted under exception 2 to section 375. It is, therefore, pertinent to address this patriarchal injustice and the resulting ambiguities in the Amendment Act of 2013.

\section{The Ambiguities and Discrimination in the Criminal Law (Amendment) Act, 2013}

The 2007 Report of the Committee on the Elimination of Discrimination against Women removes the exception of marital rape from the definition of rape. 22 Despite such recommendations, and the continued demands from women groups, the retained marital exception exhibits many discrepancies in the Amendment Act of 2013 and evidences an unnecessary policy of discrimination. ${ }^{23}$

The LCR $1971^{24}$ introduced the concept of marital rape on the basis of absence of consent when husband and wife are living apart under a decree of judicial separation or by mutual consent, to a

22 See also, Declaration on Elimination of Violence against Women, 1967 art. 14 A/RES/48/104; Convention on Elimination of All Forms of Discrimination against Women, arts. 11(1), 22, 24, 29 G.A. Res. 34/180, 34 UN GAOR Supp. (No. 46) at 193, UN Doc. A/34/46.

23 See, Ashwin Abhinav, A Comparative Analysis in Socio-legal Perspectives, 29 (1 \&2) IND. SOCIO-LEGAL J. 73 (2009); Batra Majula, Marital Rape: Is There a Remedy?, 10(1) M.D.U. L. J. 205 (2005; Suchil Kumar Satpathy, Marital Rape, 104 CR.L.J 182 (1998); Subhash Chandra Singh, Marital Rape: A feminist View, 3 S. C. J. 45 (2002).

24 Supra note 20. 
limited extent. ${ }^{25}$ Following the amendment to Child Marriage Restraint Act, 1929 (CMR Act), the LCR $1980^{26}$ provided an amendment to the marital rape exemption by increasing the age of the wife to eighteen years as it believed that since marriage with a girl below 18 years is prohibited (though it is not void as a matter of personal laws), sexual intercourse with a girl below 18 years should also be prohibited. Subsequently, this was reiterated in LCR $2000^{27}$ and also in the 2006 Draft Bill presented by the National Commission for Women which sought to criminalize marital rape. In the 2007 Report, the Committee on the Elimination of Discrimination against Women (CEDAW) has recommended the removal of the marital rape exception. ${ }^{28}$

Subsequent to the Delhi gang rape incident, the JVC was constituted. It suggested the criminalization of marital rape, reasoning that '[c]onsent will not be presumed in the event of an existing marital relationship between the complainant and the accused.'29 The Bill that was introduced in the Lok Sabha on December 4, 2012 had retained the exception, which subsequently failed to incorporate the recommendations of the JVC Report 2013, which was eventually received on April 2, 2013. On the non inclusion of marital rape, Union Home Secretary R.K. Singh clarified that accusations of rape might cause irreparable damage to the institution of marriage. ${ }^{30} \mathrm{~A}$ wife cannot be made a victim of

25 LAW COMmission OF INDIA, 42 nd Report on Indian Penal Code (1971), available at http://lawcommissionofindia.nic.in/1-50/Report42.pdf (last visited 10 Mar. 2014) at 277-279 (Explanation II to proposed section 375).

26 Supra note 19.

27 LAW COMmissiON OF INDIA, 172 ${ }^{\text {nd }}$ Report on Review of Rape Laws (2000), available at http://www.lawcommissionofindia.nic.in/rapelaws.htm. (last visited 10 Mar. 2014).

28 See also, Declaration on Elimination of Violence against Women, art. 14 A/RES/48/104; Articles 11(1), 22, 24 \& 29, Convention on Elimination of all forms of Discrimination against Women, arts. 11(1), 22, 24, 29 G.A. Res. 34/180, 34 UN GAOR Supp. (No. 46) at 193, UN Doc. A/34/46.

29 Supra note 7.

30 Bharti Jain \& Rakhi Chakrabarty, Govt justifies exclusion of marital rape as sexual offence in amended ordinance, TIMES OF INDIA, Feb. 19, 2013, available at 104 
rape and torture in order to protect the institution of marriage. Further, it is amusing that marital rape is partially recognized when the spouses are living separately, 31 but not otherwise.

\section{Difference between Age of Consent and Age of Exception}

It is submitted that since 1860, the various amendments to the IPC have ensured that the age of consent and the age of exception continue to be the same. The original IPC in 1860 placed age of consent as 10 years under the fifth clause of section 375 and age of exception as 10 years. Both were amended to 12 years by the Amendment Act 10 of 1891 as a result of the judicial decision in Queen Empress v. Hurree Mohan Mythee, 32 in which the accused caused death of his child wife, aged about 11 years and 3 months, by having sexual intercourse with her. The passing of the CMR Act raised the marriageable age to 14 years which had an impact on the IPC as well. The CMR Act was amended in 1978, laying down the minimum age of marriage to be 18 years in the case of females.

The Protection of Children from Sexual Offences Act, 2012 prohibits sexual exploitation or sexual activity with any child below the age of 18 years. ${ }^{33}$ Similarly, marriage of a woman below 18 years and a man below 21 years is a cognizable offence under the Prohibition of Child Marriage Act, 2006. Accordingly, the JVC Report suggested the removal of the marital rape exception and raising the age of consent to eighteen years. ${ }^{34}$ It is submitted that the Amendment Act of 2013 provided the age of consent at eighteen years and the age of exception was retained as fifteen years. However, the rationale behind this differentiation has not been provided by the Parliament.

http:/ / articles.timesofindia.indiatimes.com/2013-02-

19/india/37179234_1_sexual-offence-live-in-partner-home-secretary.

31 Pen. Code § 376 B.

${ }^{32}$ Queen Empress, (1890) I.L.R Cal. 49.

${ }_{33}$ Protection of Children from Sexual Offences Act, 2012, § 2(d).

${ }^{34}$ Prohibition of Child Marriage Act, 2006, § 15. 


\section{Child Marriage and Criminal Law (Amendment) Act, 2013}

The Law Commission of India noted in its Report No. 205:

"Child marriage stunts the growth and development, particularly of the girl child who is the more vulnerable partner... child marriage is a violation of human rights, compromising the development of girls and often resulting in early pregnancy and social isolation, with little education and poor vocational training reinforcing the gendered nature of poverty." 35

Child marriage has negatively impacted the rights of the child protected under the Convention on Rights of the Child, 1989. This includes the right to express their views freely, the right to protection from all forms of abuse, and the right to be protected from harmful traditional practices etc. ${ }^{36}$ The Prohibition of Child Marriage Act, 2006 (PCMA) replaced the Child Marriage Restraint Act, 1929. The PCMA has made the offences cognizable and bailable, ${ }^{37}$ and has also enhanced the punishment for male adults marrying a child and for persons performing, abetting, promoting or attending a child marriage. ${ }^{38}$

While these legal measures aim at reducing the instance of child marriage in India, the Criminal Law (Amendment) Act, 2013, on the contrary, continues to accept this crime. The exception to Section 375 IPC, which permits a husband to have sexual intercourse with his wife not being under the age of 15 years, is in direct contravention of the laws restraining marriage in which either of the party is a child, that is, a female below the age of 18

35 LAW COMmission of INDiA, Proposal To Amend The Prohibition of Child Marriage Act, 2006 And Other Allied Laws, Report No. 205 (2008), available at http:/ / lawcommissionofindia.nic.in/reports/report205.pdf.

36 UNiCEF, EARly Marriage, A Harmful Traditional Practice: A STATISTICAL EXPLORATION (2005), available at http:/ / www.unicef.org/publications/files/Early_Marriage_12.lo.pdf; Convention on the Rights of the Child, Nov. 20, 1989, 1577 U.N.T.S. 3.

37 Prohibition of Child Marriage Act, 2006, § 15.

38 India: Third and Fourth Combined Periodic Report on the CRC draft, Inputs of West Bengal State, 9-10 (2007) available at http://wcd.nic.in/crc3n4/crc3n4_1r.pdf. 
years and a male below the age of 21 years. ${ }^{39}$ This was even observed by the Delhi High Court 40 in a recent judgment; "this provision in the Indian Penal Code, 1860 is a specific illustration of legislative endorsement and sanction to child marriages."

The unnecessary ambiguity created by the alleged exception is a major lacuna in the Criminal Law (Amendment) Act, 2013.41 The National Family Health Survey of 2005-2006 (NFHS-3) carried out in twenty-nine states confirmed that $45 \%$ of women currently aged 20-24 years were married before the age of eighteen years. ${ }^{42}$ Therefore, it is pertinent to address the grave ambiguity created by the marital rape exception to the Criminal Law (Amendment) Act, 2013.

\section{Marital Rape as a Crime}

Apart from the Dissolution of Muslim Marriage Act, 1939 most personal laws recognize rape as a ground for divorce or judicial separation. ${ }^{43}$ Cruelty is also recognised as a ground for divorce by all personal laws. Rape can be brought within the ambit of the term cruelty for expanding its interpretation. ${ }^{44}$ Please refer to Table 1

\footnotetext{
39 Prohibition of Child Marriage Act, 2006, § 2 (a).

40 Court on its Own Motion (Lajja Devi) v. State 2013 Cri.L.J. 3458.

41 See, VAsudha Dhagamwar, LaW, POWER AND Justice: The Protection of Personal Rights in the Indian Penal Code 113 (2nd ed. 2010); Julia ALLISON \& LAWRENCE WRIGHTSMAN, RAPE: THE MiSUNDERSTOOD CRIME 856 (1993).

42 National Family Health Survey of 2005-2006 (NFHS-3), available at http://www.nfhsindia.org/ (The NFHS-3 facts and figures mentioned hereafter have all been retrieved from this website) (last visited Dec. 1, 2013).

43 Hindu Marriage Act, 1955, § 13 (2) (ii) (Amendment 1976); Indian Divorce Act, 1869, § 10; Parsi Marriage and Divorce Act, 1936, § 32 (d) (Amendment 1988); Special Marriage Act, 1954, § 27 (1-A) (i).

44 Hindu Marriage Act, 1955, § 13 (1) (ia) (Amendment 1976); Dissolution of Muslim Marriage act, 1939 § 2 (viii); Indian Divorce Act, 1869, § 10; Parsi Marriage and Divorce Act, 1936, § 32 (dd) (Amendment 1988); Special Marriage Act, 1954, § 27 (1) (d).
} 
which enlists the treatment of rape as a ground for divorce or cruelty in various personal laws:

\begin{tabular}{|l|l|l|}
\hline \multicolumn{3}{|c|}{$\begin{array}{l}\text { Table 1: Rape and Cruelty as Grounds for Divorce } \\
\text { under the Personal Laws }\end{array}$} \\
\hline Act & $\begin{array}{l}\text { Cruelty Provisions } \\
\text { (Section) }\end{array}$ & $\begin{array}{l}\text { Rape Provisions } \\
\text { (Section) }\end{array}$ \\
\hline $\begin{array}{l}\text { Hindu Marriage Act, } \\
\text { 1955 (Amendment 1976) }\end{array}$ & 13 (1)(ia) & 13 (2)(ii) \\
\hline $\begin{array}{l}\text { Dissolution of Muslim } \\
\text { Marriage Act, 1939 }\end{array}$ & 2 (viii) & - \\
\hline Indian Divorce Act, 1869 & 10 & 10 \\
\hline $\begin{array}{l}\text { Parsi Marriage and } \\
\text { Divorce Act, 1936 } \\
\text { (Amendment 1988) }\end{array}$ & 32 (dd) & 32 (d) \\
\hline $\begin{array}{l}\text { Special Marriage Act, } \\
\text { 1954 }\end{array}$ & 27 (1) (d) & $27(1-A)(\mathrm{i})$ \\
\hline
\end{tabular}

Personal laws provide the civil remedy of divorce and refrain from punishing the offender. Even the Domestic Violence Act, 2005 entitles a woman to seek judicial separation, but doesn't grant her a right to have her partner prosecuted. While the law is indeed a step towards recognizing the sexual abuse by partners, it still falls short of punishing the perpetrator.

In contrast, while the IPC punishes rape by a husband during judicial separation and personal laws recognize it as a ground for divorce, a husband is still permitted to seek restitution of conjugal rights. ${ }^{45}$ This too does not take into account the fact of women's consent. Such compulsion on a woman to return to the company of her husband whom she has deserted out of her own free will, is but a further aperture in the legal system ultimately legalizing marital rape.

45 Hindu Marriage Act, 1955, § 9 (Amendment 1976); Indian Divorce Act, 1869, § 32; Special Marriage Act, 1954, § 27 (1) (d). 


\section{Incongruity in Punishment for Marital and Non Marital Rape}

A significant difference, in the nature and term of punishment, exists between those committing rape on their wives and those committing rape on other women. This is reflective of the patriarchal attitude of the legislature. In the case of rape of a wife aged fifteen years or above by the husband, the perpetrator is absolved of any punishment. ${ }^{46}$ It is even more alarming that the maximum punishment sanctioned against a man involved in sexual intercourse with his wife below the age of fifteen years is less, ${ }^{47}$ even though rape of a woman under sixteen years of age is severely punished with rigorous punishment of ten years which may extend to life imprisonment. ${ }^{4}$

Refer to Table 2 below:

\begin{tabular}{|c|c|c|}
\hline \multicolumn{3}{|c|}{ Table 2: Difference in Punishment for Rape } \\
\hline Nature of Crime & $\begin{array}{l}\text { Provision } \\
\text { (Section) }\end{array}$ & Nature of Punishment \\
\hline $\begin{array}{l}\text { Rape of Wife above the age of } \\
15\end{array}$ & $\begin{array}{l}376, \\
\text { Exception } 2\end{array}$ & Not Punishable \\
\hline $\begin{array}{l}\text { Rape of any Woman } \\
\text { (Read wife below } 15 \text { years) }\end{array}$ & 376 & $\begin{array}{l}7 \text { Years extendable to } \\
\text { life imprisonment with } \\
\text { fine }\end{array}$ \\
\hline $\begin{array}{l}\text { Rape by a person holding a } \\
\text { fiduciary position towards the } \\
\text { victim by inducing or } \\
\text { seducing. }\end{array}$ & $376 \mathrm{C}$ & $\begin{array}{l}5-10 \text { years or } \\
\text { more }\end{array}$ \\
\hline $\begin{array}{l}\text { Rape by a relative, guardian or } \\
\text { teacher or a person holding } \\
\text { position of authority }\end{array}$ & $376(2)(f)$ & $\begin{array}{l}10 \text { years rigorous } \\
\text { imprisonment } \\
\text { extendable to life } \\
\text { imprisonment } \\
\text { and fine }\end{array}$ \\
\hline $\begin{array}{l}\text { Rape during separation by } \\
\text { decree or otherwise }\end{array}$ & $376 \mathrm{~B}$ & $2-7$ years \\
\hline
\end{tabular}

46 PEN. CODE $§ 37$.

47 PEN. CODE $\S 376(1)$ (It is punishable with minimum imprisonment of two years extending to seven years).

48 PEN. CODE § 376 (2) (i). 
It is another ambiguity that such sexual intercourse by husband with his wife living separately, by decree or otherwise, is punished with imprisonment for a term of two to seven years and fine. 49 While criminality is recognized when the spouses are living separately, it is unreasonable that such assault is not recognized as a crime when they are living together. Conversely, such acts should be recognized as more serious offences because it damages and questions the fiduciary relationship based on trust between the spouses.

The IPC has been considerate in recognizing the fact that people holding positions of trust with the victim should be made severely liable in cases of rape, with a punishment of for a term of ten years which may extend to life imprisonment. ${ }^{50}$ This, however, intensifies the debate as to whether a husband would qualify as holding a position of trust towards his wife. ${ }^{51}$

Further, in section 376C, the IPC penalizes the perpetrator of the crime with a punishment of more than 5 years, if he happens to be in a fiduciary relationship with the victim, even though the victim might have been instigated or seduced into giving consent. One party acts as a fiduciary to another when a party acts "for the benefit of another person, as to whom he stands in a relation implying and necessitating great confidence and trust on the one part and a high degree of good faith on the other part." 52 The Supreme Court laid down the requirements for determining fiduciary relationship between husband and wife and their children in the case of Marcel Martins v. M. Printer ${ }^{53}$ stating that the Court shall have to take into consideration the factual context in which the question arises for it is only in the factual backdrop that the existence or otherwise of a fiduciary relationship can be deduced in a given case. It is submitted that in a marriage, the

\footnotetext{
${ }^{49}$ PEN. CODE $§ 376$ B.

50 PEN. CODE $§ 376$ (2) (f).

51 Supra notes 1 and 9.

52 BLACK'S LAW Dictionary 564 (5th ed., 1979).

53 (2012) 5 S.C.C. 342; See generally, VASUdHA DHAGAMWAR, LAW, POWER and Justice: Protection of Personal Rights in the India Penal Code (2nd ed. 2009).
} 
spouses depend on each other for material and physical comforts, companionship, and love - thereby creating a fiduciary relationship. The fiduciary nature of this relationship is evidenced in section 122 of IEA, which deems communication during marriage as prolonged and is prevented from being disclosed in any court, except when one married partner is being persecuted for an offence against the other. Consequently, any evidence is inadmissible unless it is a prosecution for battery, or some related physical or mental abuse considered as cruelty.

The author would further like to highlight that under section 114A of the IEA, there is a presumption of no consent in rape cases, while in marital rape there is a presumption of consent by virtue of the exception. It is, therefore, submitted that the interplay of the IEA and section 375, IPC makes it a nearly impossible task to prosecute marital rape. Rather, such a violence should be construed as more serious offence owing to the constructive reading of Section 376C and Section 376 (2) (f) of the IPC. The above analysis reveals that the recent amendment has not addressed the issue of marital rape, rather it has granted leverage to the husband to have intercourse with his wife without her consent or against her will, which in turn will not amount to the offence of rape.

\section{Conclusion}

"When a woman is ravished what is inflicted is not merely physical injury, but 'the deep sense of some deathless shame'...Judicial response to human rights cannot be blunted by legal bigotry."

- Krishna Iyer, J. in Rafique v. State of UP. ${ }^{54}$

The UNICEF Global Report Card on Adolescents, 201255 revealed that sexual harassment and assault are endemic and more than half

541981 S.C.R. (1) 402.

55 Kounteya Sinha, $57 \%$ of boys, 53\% of girls think wife beating is justified, TIMES OF INDIA, Apr. 25, 2012 available at http:/ / articles.timesofindia.indiatimes.com/2012-0425/india/31398208_1_domestic-violence-spousal-violence-centre-forsocial-research. 
of the young males think that beating their wives is justified. Ideally, the exception to section 375 of the IPC should be removed by the Parliament. However, owing to the presence of a diverse system of personal laws, any radical overhaul of the structure of sexual offences is not advisable. ${ }^{56}$ In the absence of any legislative action, it is desirable that the judiciary builds upon the existing legal structure by (i) interpreting marital rape as a crime under section $376 \mathrm{C}$ or section 376 (2) (f) of the IPC, 57 and (ii) striking down the exception by declaring it ultra vires the Constitution. ${ }^{58}$ Respecting the words of Justice Krishna Iyer and having regard to the exposition of the law in Ashok Kumar Thakur v. Union of India59 that the Constitution embraces substantive equality, it is desirable that a married woman is treated at par with other women by defying the myth of irrevocable consent to marital rape.

${ }^{56}$ D. Nicolsan \& L. BibBings, Feminist PeRSPeCtive 185 ( $1^{\text {st }}$ ed. 2000).

57 Supra notes 50-53.

58 Supra notes 16-21.

59 (2008) 6 S.C.C. 1. 